\title{
Legal Tech and Lawtech: Towards a Framework for Technological Trends in the Legal Services Industry
}

\author{
Ciaran M. Harper and S. Sarah Zhang
}

\begin{abstract}
The use of legal technology (legal tech) and the lawtech ecosystem of legal start-ups has experienced tremendous growth in recent years. To provide a structured approach of analysing IT innovations in the legal sector, we propose a framework for lawtech applications, classifying them into three groups: internal, B2C and B2B applications. In the context of this framework, we examine technological trends in lawtech and their potential to support and transform processes in specific areas of business or personal law. We acknowledge that within lawtech there is a gap between the areas of interest of legal practitioners, IT professionals and academic researchers, and that some areas have received considerable attention by these groups, while other areas have been left relatively unexplored by one or more of these groups. However, the growing interest by legal practitioners in advanced technology such as artificial intelligence (AI) and natural language processing (NLP) is further closing the gap between academic research, IT professionals and legal practice.
\end{abstract}

\section{Introduction}

Digital innovations have become ubiquitous in sectors such as finance, insurance and more recently the legal sector. While the use of technology in legal contexts has increased over the last decades, the more recent growth of the ecosystem of legal start-ups has garnered significant attention and interest in IT applications in the legal

The views expressed here are solely our own.

C. M. Harper

Fletchers Solicitors, Southport, Merseyside, UK

e-mail: ciaranharper@fs.co.uk

\section{S. S. Zhang $(\bowtie)$}

Alliance Manchester Business School, University of Manchester, Manchester, UK

e-mail: sarah.zhang@manchester.ac.uk 
sector by investors and clients. The increase in investment in legal technology (FT 2019) and an increase in demand by clients (Law Society 2019b) have led to the 'lawtech' and 'legal tech' developments gaining further traction.

Lawtech is broadly defined as 'technologies which aim to support, supplement or replace traditional methods for delivering legal services, or transactions; or which improve the operation of the justice system' (Law Society 2019a). Some sources note that there are differences between the terms legal tech and lawtech (see, e.g., Legal Geek 2018): the former focusses on technological applications which support traditional legal processes, while the latter is used to describe the more recent developments in the legal start-up industry. The expanding lawtech ecosystem includes applications that support legal processes using more advanced technology such as machine learning (ML) and artificial intelligence (AI), as well as applications which seek to provide alternatives to traditional legal processes, such as marketplaces for legal services. We follow this distinction and use the term legal tech for applications which provide technological support for legal practitioners, whereas we use lawtech more broadly for legal tech applications using more advanced technology, as well as legal start-ups which seek to disrupt and replace some legal processes.

The aim of this chapter is to outline recent trends in lawtech and legal tech in a structured framework and provide an overview of recent academic literature in the area. In particular, we propose a lawtech framework which classifies applications into three groups: internal, Business-to-Business (B2B) and Business-to-Consumer (B2C) applications. Furthermore, we highlight that the context of the specific area of law is vital for the application of different types of technologies to different areas of law. We specifically distinguish between personal and business law and identify major technology drivers for lawtech. In the context of our framework for lawtech applications we discuss the suitability of different technological solutions in different areas of law. Based on the academic discussions on lawtech and legal tech, we discuss certain gaps between the academic discussions in computer science and law, as well as differences from the practice-founded discourse, and point out areas for future research.

\section{Background/Foundations}

In this section, we set out the different areas of law, their potential for automation and the use of lawtech applications. We further discuss recent trends of lawtech in practice and the lawtech research topics in various areas of the academic literature. 


\subsection{The Role of Technology in Different Areas of Law}

The areas of law can be broadly categorised into personal law (legal disputes concerning individuals) and business law (legal issues concerning businesses). In personal law, some of the main areas include: property and housing; wills, trusts and probate; personal injury; consumer and civil rights; crime; employment; family; immigration; banking and debt; and social welfare. Business law includes some of the following areas: commercial law, energy and utilities, regulation and compliance, IT and intellectual property, and litigation and dispute resolution (see University of Law 2020). We note that some areas of law fall into both personal and business law. ${ }^{1}$ The areas of practice for lawyers can be further characterised as 'contentious' (involving courts and/or tribunals) or 'non-contentious' (not involving courts and/or tribunals, and which are typically more transactional).

Examples of (mostly) non-contentious areas may include:

- Wills and probate

- Conveyancing and property law

- Corporate finance and corporate commercial

- Energy

- Transportation

Examples of (mostly) contentious areas of legal practice may include:

- Criminal law

- Family law

- Civil litigation

- Immigration

- Personal injury

- Employment law

It is important to appreciate that these areas do frequently overlap in practice, and there is no hard boundary between contentious and non-contentious work. While some lawyers will mostly do contentious work (e.g. personal injury lawyers) and others do mostly non-contentious work (e.g. conveyancers), others will carry out a mixture of work (e.g. a specialist in employment law will handle both contentious matters, such as a claim for unfair dismissal, and non-contentious matters, such as standard employment contracts). Furthermore, some areas of law can focus on the non-contentious aspects (e.g. dry shipping law, the non-contentious aspect of shipping law) and others on the contentious aspects of one overarching practice area (e.g. wet shipping law, the contentious part of shipping law). As there is a very wide range of legal practice, lawtech solutions therefore need to cater to the specific needs of each area of law.

\footnotetext{
${ }^{1}$ The various areas of law are further subject to various rules regimes as well, for example the Civil Procedure Rules or the Criminal Procedure Rules, which set out assorted protocol requirements for the formatting of evidence, service and submission of documents, applications to Court, etc.
} 
We argue that non-contentious law is easier to automate as it involves fewer disagreements on facts or legal interpretations. A good example of a non-contentious area would be conveyancing (the process of transferring real estate from one party to another, typically as a sale of property such as buying a house). This is typically a formulaic process which in most cases contains the same steps in the same order. It is therefore an area which might be more prone to automation with the assistance of legal tech.

However, recent lawtech applications also offer solutions for the contentious areas of law for both individuals and businesses. An example of a contentious area of law which has been transformed by technology would be personal injury. Due to the introduction of a government portal for the issuance of claims regarding personal injury (the first of which was in the sub-field of road traffic accidents), the process of this mostly contentious area of law has been significantly standardised, which has streamlined the claims process and thus increased the efficiency of the handling of personal injury claims.

\subsection{Recent Trends in Legal Technology}

To provide an overview of recent trends in lawtech, we summarise different areas of lawtech applications in Table 1, based on areas of applications identified by the Law Society (2019b), Cunningham et al. (2018) and Susskind (2017). Some areas of lawtech applications focus on supporting traditional legal processes in established law firms, including practice management, risk and compliance, legal research, contract analysis and intellectual property. Commonly used technologies and methods in this area include cloud-based services, data analytics and process automation.

In recent years, the lawtech start-up sector has gained significant momentum, with some potential for disruptive effects on the traditional legal sector. Areas of applications for lawtech start-ups include legal-docs-as-a service, e-billing, DIY law and marketplaces for legal services.

In terms of specific technologies, $\mathrm{AI} / \mathrm{ML}$ and blockchain have been commonly mentioned as gamechangers for the legal sector. As noted by the Law Society (2019b), the specific use cases for some of these technologies in a legal context are still relatively sparse. Mik (2017) and Rivas et al. (2018) further comment on the technical and legal limitations of using blockchain technology for contractual transactions, as they are 'incapable of enforcement in a legal sense' (Rivas et al. 2018, p.2). However, there might be potential for the use of blockchain in commercial and business law, for example in the conveyancing and property market. 
Table 1 Areas of application for lawtech

\begin{tabular}{|c|c|}
\hline $\begin{array}{l}\text { Area of } \\
\text { application }\end{array}$ & Area description (cf. Law Society 2019b; Susskind 2017) \\
\hline $\begin{array}{l}\text { Practice } \\
\text { management }\end{array}$ & $\begin{array}{l}\text { Solutions for case management, accounting and legal processes, which } \\
\text { are frequently cloud-based }\end{array}$ \\
\hline $\begin{array}{l}\text { Risk and } \\
\text { compliance }\end{array}$ & $\begin{array}{l}\text { Process automation (PA) to streamline compliance activities and reduce } \\
\text { risk to businesses, such as tech solutions to reduce onboarding time for } \\
\text { new clients, or to prevent data breaches such as incorrectly addressed } \\
\text { emails }\end{array}$ \\
\hline $\begin{array}{l}\text { Legal } \\
\text { research/analytics }\end{array}$ & $\begin{array}{l}\text { Legal spend and legal trend analysis using predictive analytics/data } \\
\text { analytics and the use of technology to understand aspects of service } \\
\text { delivery to clients and associated commercial models }\end{array}$ \\
\hline $\begin{array}{l}\text { Contract analy- } \\
\text { sis/management }\end{array}$ & $\begin{array}{l}\text { Automation of standard contracts or using natural language processing } \\
\text { (NLP) and predictive analytics to consider documents so as to, for } \\
\text { example, consider when best to settle a claim, or decide how long a } \\
\text { matter is likely to take }\end{array}$ \\
\hline $\begin{array}{l}\text { Intellectual } \\
\text { property }\end{array}$ & $\begin{array}{l}\text { Technology supporting the research and protection of trademarks, } \\
\text { cost/benefit analysis for licensing and trademark data validation }\end{array}$ \\
\hline E-discovery & $\begin{array}{l}\text { Technology to facilitate easy search and retrieval of electronically stored } \\
\text { information, information transfer to other parties and analysis of } \\
\text { information from other parties }\end{array}$ \\
\hline DIY law & $\begin{array}{l}\text { Apps or chatbots which are used by clients as a first port of call to seek } \\
\text { legal advice or engage with legal processes }\end{array}$ \\
\hline $\begin{array}{l}\text { Legal-docs-as-a- } \\
\text { service }\end{array}$ & $\begin{array}{l}\text { Providers of access to a library of standardised legal documents and/or } \\
\text { access to a solicitor }\end{array}$ \\
\hline Marketplaces & $\begin{array}{l}\text { Online platforms which provide transparency in terms of both pricing and } \\
\text { process for clients. Examples include a 'GoCompare'-type comparison } \\
\text { site or a platform similar to Upwork, where clients can post a legal } \\
\text { job/service they require, and firms can then compete for the business }\end{array}$ \\
\hline E-billing & $\begin{array}{l}\text { E-billing solutions are moving towards a real-time transparency of billing } \\
\text { which would provide a better view of work-in-progress and reduce } \\
\text { dependency on traditional costs draftsmen }\end{array}$ \\
\hline $\begin{array}{l}\text { Online dispute } \\
\text { resolution }\end{array}$ & $\begin{array}{l}\text { Online platforms to exchange message and documentary evidence } \\
\text { between claimants and defendants to support their points in the dispute, } \\
\text { with potential to be further enhanced by AI technology. }\end{array}$ \\
\hline
\end{tabular}

\subsection{Lawtech Research}

Lawtech-related research involves multiple disciplines, centred around areas of law and computer science. Research topics on the use of technology in the legal sector have attracted attention from the academic community in both law and computer science in recent decades (since at least the 1980s).

On one side, there are several conferences and journals in computer science dedicated to topics around the intersection of law and technology. Evidently, topics involving AI are a major focus of the computer science community. Research articles in this area cover a wide range of topics, including studies on judicial decision support (Leith 1998), e-discovery (Hogan et al. 2010), the use of machine 
learning to predict court decisions (Medvedeva et al. 2020), analyses of online terms of service agreements (Lippi et al. 2019; Braun et al. 2019), legal expert systems (Ashley 1992; Visser and Bench-Capon 1998; Dimyadi et al. 2019), online negotiation systems (Barnett and Treleaven 2018) and legal knowledge systems and ontologies (Kurematsu and Yamaguchi 1997; Leone et al. 2020), amongst a variety of other topics. However, Oskamp and Lauritsen noted in 2002 that "[they] are frustrated not to be able to cite any fully unqualified examples of "true AI" that have been successfully deployed in the "real world" of law practice' (Oskamp and Lauritsen 2002, p. 227), indicating a significant gap between academic research on technological solutions and its adoption by legal practice.

On the other side, the interest of research communities in other areas has increased in recent years. Rather than focussing on the specific technological solutions, research in the area of law and innovation studies examines legal technology and lawtech as a driver of innovation and its impact on the legal profession. For example, Webley et al. (2019) provide an overview of different narratives of the engagement of legal practitioners with lawtech and focus on the long-term effects of technology on the legal sector. On one side, they present the hypothesis of a replacement of lawyers by technology and AI as suggested by Susskind (1998, 2017). On the other extreme, they describe a defensive stance of the legal sector towards technological innovations as 'status professionalism'. More moderate narratives include Christensen (1997)'s concept of a technological disruptor, where the legal sector will be significantly transformed by the technological innovations. Finally, Webley et al. (2019) propose the narrative of 'adaptive professionalism', which accepts that the legal field needs to adopt and develop new technology-related skills and competences, but also accounts for the diversity and complexity of the legal sector (cf. Webley et al. 2019, p.17). However, with the increase in interest from the practitioner community in AI/ML and NLP applications more recently, the studies related to these topics have received more attention and have been developed further (cf. Dale 2019; Sun et al. 2020). Other academic studies which focus on the potential for innovation and on the ecosystem of legal start-ups apply theories and methodologies from innovation studies and entrepreneurship (cf. Cunningham et al. 2018; Hongdao et al. 2019; Sako et al. 2019).

Finally, there are increasing calls for the training of legal professionals to include technological aspects, from the use of digital legal resources (Jackson 2016) to the transformation of the legal curricula to include legal tech topics (Ryan 2020). More specifically, Ireland and Hockley (2020) survey legal tech programmes at undergraduate (the Access to Justice module offered by the University of Manchester and the Lawtech module offered by the University of York) and postgraduate (LLM in the Legaltech programme offered by Swansea University and the Future of Legal Practice module offered by University College London) levels. Initiatives involving the academic community and legal practice, such as the Manchester Law and Technology Initiative (Law Society Gazette 2018), further provide a platform to shape law programmes in higher education, but also encourage the discourse between academic researchers and legal practitioners. 


\section{A Framework for Lawtech Applications}

Based on our discussion in the previous section, we propose a structured lawtech framework which combines different areas of law with a wide range of technologies and classifies lawtech applications into three areas. The framework for lawtech applications is presented in Fig. 1.

The first layer of the framework broadly classifies the areas of law into personal law and business law. Both of these areas of law include more and less contentious areas. We further include a second layer which presents technologies that have been commonly applied in recent lawtech applications, such as AI/ML, NLP, process automation, cloud-based services and blockchain technology. We note that the second layer in Fig. 1 highlights recent trends, but is not an exhaustive list of technologies applied in lawtech. Finally, our lawtech framework categorises legal

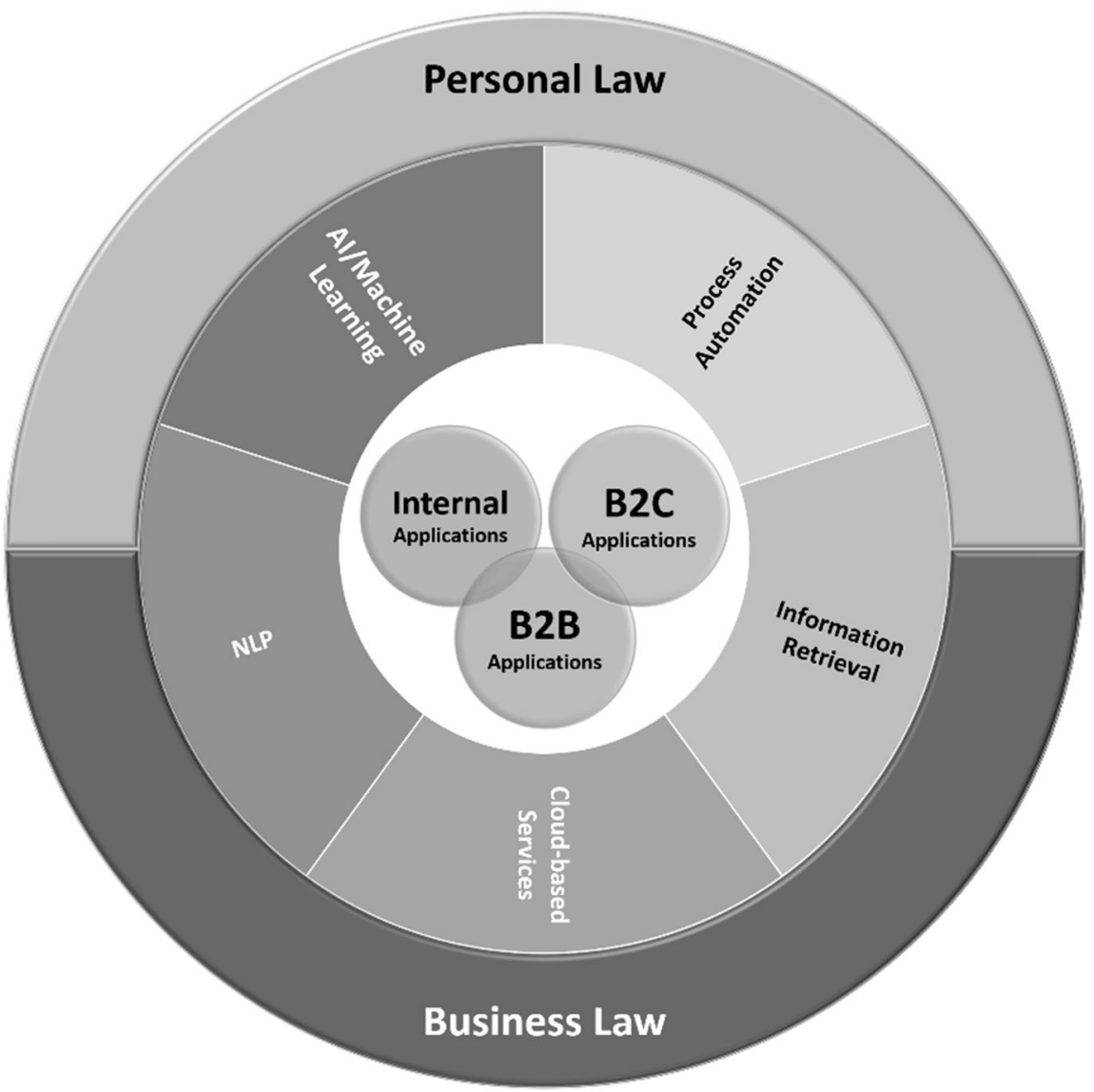

Fig. 1 Framework for lawtech applications 
tech into three broad areas, each supporting the legal practice in a different way: (1) Business-to-Consumer (B2C) applications, (2) Business-to-Business (B2B) applications and (3) internal applications. Our classification is broadly in line with previous classifications of lawtech applications (cf. Law Society 2019b; Pourshafie 2020), although in our classification, we focus on the stakeholders involved in a specific lawtech application.

\subsection{B2C Applications}

Business-to-Consumer (B2C) applications comprise those which are more 'frontend' and client-facing, enabling greater interaction between the lawyer and their client. This is useful for both personal and business clients, albeit for slightly different reasons according to their specific needs. These technologies would therefore facilitate and strengthen the rule of law and access to justice.

Examples of B2C technologies may include:

- DIY law: This area covers applications which would be a front line for client engagement with the law so that if they have a legal question, they can either answer it themselves or be in a position to describe the issues more cogently to a lawyer and thus receive quicker and more relevant advice. An example would be e-learning resources and AI chatbots which could answer simple legal questions, and if the issue turned out to be more complex, could refer the client to a lawyer and provide that lawyer with a summarised version of the prospective client's issues.

- Legal-docs-as-a-service: In this area, a basic service would simply be access to a library of legal precedent documents, but a more sophisticated application could include a program which asks clients questions about their requirements and then generates a document (e.g. a lease or a will) based on their stated needs. This type of service could be either subscription-based or paid for with a one-off fee.

- Marketplaces: This covers any type of online platform which increases the availability and price transparency of legal work. At a basic level it would include the type of price comparison website which is already in wide use for insurance and household utilities (e.g. GoCompare) and review websites such as Trustpilot, but could also include services similar to Upwork, a website which is a marketplace for freelance writing, editing and translation.

- Alternative/online dispute resolution (ADR/ODR): This area relates to platforms where parties involved in a dispute can exchange message and documentary evidence to support their points in the dispute. This type of service is already in use in a few places: eBay provides for online dispute resolution between traders and customers, and the European Commission has an online dispute resolution platform. In the future, a more advanced application of ODR could use AI to resolve disputes between parties without having to go through 
a formal litigation process. All these methods include a third party (i.e. not one of the parties involved in the dispute) providing assistance either to give a view on which party is correct or to bridge the gap between them so the parties in the dispute can reach an accommodation themselves. It is therefore easy to envisage a situation where AI replicates this functionality to a greater or lesser degree and is incorporated into current ODR platforms.

Computer science research from the 1980s up until the 2000s has focussed on issues surrounding the digitalisation of legal information and its interpretation. More recently, research has emerged which is more applications-focussed, with papers analysing the potential of ODR (Barnett and Treleaven 2018), online platforms for legal information (Ostendorff et al. 2020) or terms of services (Lippi et al. 2019; Braun et al. 2019), among others. Similar to the practitioner community, the attention of the academic community has also shifted slightly from legal technology which supports existing legal processes, to also analysing and proposing alternatives to the same legal processes.

\subsection{B2B Applications}

Business-to-Business (B2B) applications in the legal arena include, as in other sectors, applications which facilitate communication between businesses, but also, given the specific legal context, large organisations which are business-like, such as courts and tribunals, barristers' chambers, hospital trusts and mediation services.

Examples of B2B technologies may include:

- Cloud-based services and secure document transfer: Applications of this sort would be the 'bread and butter' for B2B applications in the legal sector. Law firms need to transfer documents to other law firms, courts and tribunals, barristers, enquiry agents and so on many times every working day. Having a quick and secure method for doing this which integrates well with a law firm's other systems is therefore extremely desirable.

- Data streams: The provision of legal services is frequently assisted by businesses, which in turn provide services to law firms. There is accordingly significant scope for these services to be streamlined and integrated into the dayto-day operation of legal service providers via technical means. Examples may include:

- Trust account monitoring/auditing by an accredited auditing provider

- Trusted information exchange/blockchain - for example with regard to the ownership of intellectual property

- Partnering with complementary firms: not every law firm provides every conceivable legal service, but many do operate referral agreements between themselves for those circumstances where they are approached by a potential client with a legal need they cannot meet. 
- E-discovery: In common law jurisdictions such as England and Wales, litigation is carried out on a 'cards on the table' basis - parties must disclose all documents in their possession which either support or weaken their own case as well as support or weaken the other side's case. For this purpose, 'document' is an extremely broad term and can include information stored electronically. Ediscovery applications therefore include applications which facilitate easy search and retrieval of electronically stored information, as well as the transfer of the same to other parties and analysis of documents received from other parties.

- E-billing: Legal costs are a good example of an industry which runs in parallel to law firms. For less contentious matters, law firms will be able to produce their own bills; and effective software solutions to do this quickly and easily, as well as to monitor the efficiency of individual lawyers, are desirable for obvious reasons. In more contentious matters, law firms will frequently engage the services of an external costs draftsman to prepare their bills and, if necessary, argue in court that the size of the bill is reasonable and proportionate. Therefore, an ebilling application would ideally be able to carry out the monitoring noted above, and also integrate easily and securely with an external provider such as a costs draftsman and the court.

Some of the areas of B2B applications overlap with the area of B2C applications, for example ODR for contentious business-law-related cases, or subscription-based models for legal services within the context of DIY law. However, most B2B applications are more specialised in the specific area of law and the legal process which needs to be followed.

E-discovery has received much attention from both a legal and a technological perspective (Baron 2011; Hogan et al. 2010), with the latter focussing more on aspects of information and text retrieval (Oard et al. 2008). There has also been an increase in interest and research around the support and automation of court processes (cf. Leith 1998; Susskind 2019). Blockchain technology features among the widely mentioned technologies in this area in the context of smart contracts, although there are certain limitations of the technology and its applications in a legal context (as mentioned above). Despite a significant amount of research in certain areas of applications, we note that some B2B applications, such as cloudbased legal services, have not attracted as much attention as other areas.

\subsection{Internal Applications}

Internal applications comprise those applications which support the functioning of a legal practice but which a client will not directly interact with. Therefore, this may include not only applications which are concerned solely with the practice itself, such as those which will track KPIs, the business's accounts and other management information, but also applications which support lawyers in doing work for clients. 
Examples of these applications may include:

- Practice management: As indicated in Table 1, this includes applications for invoice tracking, accounting and case management (which incorporates both filing and task management), but also the substantive processes of being a lawyer in practice, such as time recording and dictation software. Examples here would include Proclaim, which is widely used in the Personal Injury sector and is a 'one-stop' platform which incorporates filing, task management and accounting processes, or Dragon dictation software.

- Risk and compliance: These applications exist to minimise the liabilities to any legal practice by ensuring that processes which minimise risk are 'baked in' to day-to-day tasks. This could be mandatory workflows to check a new client's identity for money-laundering (law firms being particularly at risk of attempted money laundering) and conflict purposes, or email software with safeguards to prevent phishing attempts or data breaches due to misaddressed emails.

- Contract analysis/management: These applications currently appear to be in their infancy, but could eventually include automation of standard contracts (potentially using blockchain) or NLP to analyse documents and consider the level of legal risk in any given situation.

- Legal research/analytics: These applications include straightforward database applications which collate up-to-date legal resources (examples include LexisNexis and Westlaw) and also applications which can help to formulate advice to a client. An example of this would be piCalculator, an online application which helps to derive the value of a client's legal claim based on a number of factors including their age, education level, income and stated losses to date.

- Intellectual property: Intellectual property applications comprise, to a large extent, automated search and analysis tools. When registering a trademark or a patent, it is critical to establish that the phrase, image, process or other intellectual property element has not already been registered. A simple application would be the sort of word search function which is common to many applications already, but more sophisticated applications would include elements of NLP and AI to weed out non-relevant matches and provide analysis of the new trademark and existing ones, perhaps with commentary on possible litigation risk.

Some of the applications presented here, such as case management applications and IT support to minimise compliance risk, have been widely adopted by law firms, resulting in large cost savings and high efficiencies. The research in the area of AI and law has supported the development of management applications. As more advanced AI and ML applications could be able to provide a deeper level of analysis of legal information, they might provide further potential for automation in these areas. 


\section{Discussion and Conclusion}

We propose a structured framework for the classification of lawtech applications. Specifically, we distinguish between internal, B2B and B2C applications, which are further embedded into different areas of law and recent technological trends. We postulate that the specific area of law is vital for understanding the effectiveness and impact of a specific lawtech application. In particular, the level of contentiousness in an area of law is one determinant for suitable lawtech applications in this particular area of law.

In considering the different areas of focus for academic research and practitioner discussions, we find gaps between the academic research and IT community and the adoption in legal practice. Within computer science, there is a large body of research on the use of AI in a legal context. Researchers in other areas mostly apply theoretical approaches and methodologies borrowed from innovation studies and entrepreneurship to analyse the ecosystem of lawtech start-ups or to provide predictions regarding the effects of technology on the legal sector as a whole. In contrast, practitioners are mainly focussed on legal technology supporting traditional legal processes, an area which is only partially covered in the context of recent work on $\mathrm{AI}$ and law.

Some of the gaps between legal practice and academia provide potential for future research. More research is necessary to support the current developments of lawtech applications and to provide the relevant background from areas of management and business studies. The gap between the research and applications in IT and the needs of the legal practice has to be further closed for a more fruitful discourse between academia, the IT community and legal practitioners.

Finally, we note that our study uses sources from the UK, such as the Law Society of England and Wales, and examples of academic institutions in the UK. We claim that the general classification into areas of law and their potential for technological innovation also applies to other jurisdictions, though the application in practice would certainly depend on the law of the specific country/jurisdiction. However, international studies on lawtech developments in different countries would further the understanding of country-specific (and law-system-specific) factors which influence the lawtech and legal tech sectors.

Going forward, we believe that a sustained interest in lawtech and legal tech applications will further close any gaps between academic research and legal practice and provide further insights into the role of technological innovation in law and legal practice.

\section{References}

Ashley KD (1992) Case-based reasoning and its implications for legal expert systems. Artificial Intelligence and Law 1:113-208. https://doi.org/10.1007/BF00114920

Barnett J, Treleaven P (2018) Algorithmic Dispute Resolution-The Automation of Professional Dispute Resolution Using AI and Blockchain Technologies. The Computer Journal 61:399408. https://doi.org/10.1093/comjnl/bxx103 
Baron JR (2011) Law in the Age of Exabytes: Some further Thoughts on 'Information Inflation' and Current Issues in E-Discovery Search. Richmond Journal of Law \& Technology 17:1-33

Braun D, Scepankova E, Holl P, Matthes F (2019) The Potential of Customer-Centered LegalTech. Datenschutz und Datensicherheit - DuD 43:760-766. https://doi.org/10.1007/s11623-019$1202-7$

Christensen C (1997) The Innovator's Dilemma. Harvard Business Review Press

Cunningham A, James AD, Taylor P, Tether B (2018) Disruptive Technologies and Legal Service Provision in the UK: A Preliminary Study

Dale R (2019) Industry Watch Law and Word Order: NLP in Legal Tech. Natural Language Engineering 25:211-217. https://doi.org/10.1017/S1351324918000475

Dimyadi J, Bookman S, Harvey D, Amor R (2019) Maintainable process model driven online legal expert systems. Artificial Intelligence and Law 27:93-111. https://doi.org/10.1007/s10506018-9231-3

Financial Times, Croft J (2019) UK lawtech sector gets kick-start from increased investment. In: Dec 5. https://www.ft.com/content/ec995c7e-16bf-11ea-9ee4-11f260415385. Accessed 22 Oct 2020

Hogan C, Bauer RS, Brassil D (2010) Automation of legal sensemaking in e-discovery. Artificial Intelligence and Law 18:431-457. https://doi.org/10.1007/s10506-010-9100-1

Hongdao Q, Bibi S, Khan A, et al (2019) Legal technologies in action: The future of the legal market in light of disruptive innovations. Sustainability 11:1-19. https://doi.org/10.3390/ su11041015

Ireland C, Hockley R (2020) A call for introducing LegalTech in the classroom. Computer Law \& Security Review 36:105399. https://doi.org/10.1016/J.CLSR.2020.105399

Jackson D (2016) Human-centered legal tech: integrating design in legal education. The Law Teacher 50:82-97. https://doi.org/10.1080/03069400.2016.1146468

Kurematsu M, Yamaguchi T (1997) A Legal Ontology Refinement Support Environment Using a Machine-Readable Dictionary. Artificial Intelligence and Law 5:119-137. https://doi.org/ 10.1023/A: 1008220029904

Law Society (2019a) Introduction to LawTech - A practical guide to legal technology

Law Society (2019b) Lawtech Adoption Research

Law Society Gazette (2018) Firms join university's legal tech initiative. In: Law Society Gazette 28 September 2018. https://www.lawgazette.co.uk/practice/firms-join-universitys-legal-techinitiative/5067716.article. Accessed 23 Oct 2020

Legal Geek (2018) \#LegalTech v \#LawTech - WTF? In: Legal Geek. https://www.legalgeek.co/ learn/lawtech-legaltech-wtf/. Accessed 23 Oct 2020

Leith P (1998) The Judge and the Computer: How Best "Decision Support"? Artificial Intelligence and Law 6:289-309. https://doi.org/10.1023/A:1008226325874

Leone V, Di Caro L, Villata S (2020) Taking stock of legal ontologies: a feature-based comparative analysis. Artificial Intelligence and Law 28:207-235. https://doi.org/10.1007/s10506-01909252-1

Lippi M, Pałka P, Contissa G, et al (2019) CLAUDETTE: an automated detector of potentially unfair clauses in online terms of service. Artificial Intelligence and Law 27:117-139. https:// doi.org/10.1007/s10506-019-09243-2

Medvedeva M, Vols M, Wieling M (2020) Using machine learning to predict decisions of the European Court of Human Rights. Artificial Intelligence and Law 28:237-266. https://doi.org/ 10.1007/s10506-019-09255-y

Mik E (2017) Smart contracts: terminology, technical limitations and real world complexity. Law, Innovation and Technology 9:269-300. https://doi.org/10.1080/17579961.2017.1378468

Oard DW, Hedin B, Tomlinson S, Baron JR (2008) Overview of the TREC 2008 Legal Track. In: Proceedings of the seventeenth text retrieval conference proceedings (TREC 2008)

Oskamp A, Lauritsen M (2002) AI in Law Practice? So far, not much. Artificial Intelligence and Law 10:227-236. https://doi.org/10.1023/A:1025402013007 
Ostendorff M, Blume T, Ostendorff S (2020) Towards an Open Platform for Legal Information. In: Proceedings of the ACM/IEEE Joint Conference on Digital Libraries in 2020. ACM, New York, NY, USA, pp 385-388

Pourshafie Q (2020) Introducing the Future Framework for Legal Practice (Part 1) - Legal Tech Weekly. In: Legal Tech Weekly. https://contractbook.com/legaltechweekly/introducingthe-future-framework-for-legal-practice-part-1. Accessed 19 Oct 2020

Rivas AG, Tsyganova M, Mik E (2018) Smart Contracts and their Identity Crisis. In: ICIS 2018 Proceedings

Ryan F (2020) Rage against the machine? Incorporating legal tech into legal education. The Law Teacher 1-13. https://doi.org/10.1080/03069400.2020.1805927

Sako M, Qian M, Verhagen M, Parnham R (2019) Scaling Up Firms in Entrepreneurial Ecosystems: FinTech and LawTech Ecosystems Compared. 1-48

Sun C, Zhang Y, Liu X, Wu F (2020) Legal Intelligence: Algorithmic, Data, and Social Challenges. In: Proceedings of the 43rd International ACM SIGIR Conference on Research and Development in Information Retrieval. ACM, New York, NY, USA, pp 2464-2467

Susskind RE (1998) The Future of Law: Facing the Challenges of Information Technology. Clarendon Press

Susskind RE (2017) Tomorrow's lawyers: An introduction to your future. Oxford University Press, Oxford

Susskind RE (2019) Online Courts and the Future of Justice. Oxford University Press

University of Law (2020) Legal Practice Areas. https://www.law.ac.uk/employability/legalpractice-areas/

Visser PRS, Bench-Capon TJM (1998) A Comparison of Four Ontologies for the Design of Legal Knowledge Systems. Artificial Intelligence and Law 6:27-57. https://doi.org/10.1023/ A:1008251913710

Webley L, Flood J, Webb J, et al (2019) The Profession(s)' Engagements with LawTech: Narratives and Archetypes of Future Law. Law, Technology and Humans 1:6-26. https://doi.org/10.5204/ lthj.v1i0.1314

Ciaran M. Harper is a solicitor and senior litigation executive at Fletchers Solicitors of Southport and Manchester, United Kingdom. He completed his LLB at the College (now University) of Law, Chester, and completed his training contract at BTMK Solicitors of Southend-on-Sea, Essex, United Kingdom, and was admitted as a solicitor in 2012. His main area of practice is clinical negligence, acting for claimants in a range of matters, including, but not limited to, dental, cancer and ophthalmology cases.

S. Sarah Zhang is an assistant professor of finance at Alliance Manchester Business School of the University of Manchester, United Kingdom. She received her $\mathrm{PhD}$ in Economics from Karlsruhe Institute of Technology, supervised by Professor Dr. Christof Weinhardt. Her research focusses on market microstructure, technological innovations in financial markets and law, and experimental finance. Her work has been published in the Journal of Banking and Finance, the Journal of Futures Markets and the Financial Review, amongst others. 
Open Access This chapter is licensed under the terms of the Creative Commons Attribution 4.0 International License (http://creativecommons.org/licenses/by/4.0/), which permits use, sharing, adaptation, distribution and reproduction in any medium or format, as long as you give appropriate credit to the original author(s) and the source, provide a link to the Creative Commons licence and indicate if changes were made.

The images or other third party material in this chapter are included in the chapter's Creative Commons licence, unless indicated otherwise in a credit line to the material. If material is not included in the chapter's Creative Commons licence and your intended use is not permitted by statutory regulation or exceeds the permitted use, you will need to obtain permission directly from the copyright holder. 